\title{
BENEFICIAL EFFECTS OF CLOACAL BACTERIA ON GROWTH AND FLEDGING SIZE IN NESTLING PIED FLYCATCHERS (FICEDULA HYPOLEUCA) IN SPAIN
}

\author{
Juan Moreno, ${ }^{1,3}$ Víctor Briones, ${ }^{2}$ Santiago Merino, ${ }^{1}$ Cristina Ballesteros, ${ }^{2}$ Juan J. \\ SANZ, ${ }^{1}$ AND GUSTAVO TOMÁs ${ }^{1}$ \\ ${ }^{1}$ Departamento de Ecología Evolutiva, Museo Nacional de Ciencias Naturales-CSIC, J. Gutiérrez Abascal 2, \\ E-28006 Madrid, Spain; and \\ ${ }^{2}$ Departamento de Sanidad Animal, Facultad de Veterinaria, Universidad Complutense, E-28040 Madrid, Spain
}

\begin{abstract}
Effects of bacteria on avian hosts in the wild have received little attention until recently. Whereas the pathogenic effects of bacteria are well known, positive effects of symbiotic bacteria are more rarely considered. Nestling growth has important repercussions for offspring fitness in avian populations and may be affected by microbial colonization of the gut. Enterococcus faecalis is a common opportunistic pathogen, whereas E. faecium has been used as a growth promoter because it interacts competitively with pathogenic bacteria, E. faecalis included. We followed the growth in tarsus length and mass of 18 Pied Flycatcher (Ficedula hypoleuca) broods. Chicks were weighed and measured on days 4, 8, 10, and 13 after hatching. On day 13, wing length was also measured and cloacal swabs were taken of two chicks in each brood for detection of enterococci. In all, the methods used allowed us to detect six species of bacteria among a possibly much richer community. Most chicks had E. faecalis, whereas E. faecium was less prevalent. There was a negative association between scores for $E$. faecalis and for the rest of the species pooled. The presence of E. faecalis showed no detectable association with nestling mass or size at any age, whereas the presence of the other species showed significantly positive associations with mass and size on day 13, but not before. Presence of E. faecium on its own was positively associated with nestling mass and size shortly before fledging. E. faecium may act as a growth promoter in the wild through its competitive interactions with facultative pathogenic bacteria. The presence of some microbes are critically important in avian growth and development. Received 5 August 2002, accepted 13 March 2003.
\end{abstract}

RESUMEN.-Los efectos de bacterias sobre aves hospedadoras en estado salvaje han recibido escasa atención hasta hace poco. Mientras los efectos patogénicos de bacterias son bien conocidos, los efectos positivos de bacterias simbiontes han sido poco considerados. El crecimiento de pollos tiene importantes repercusiones para la eficacia biológica de la descendencia en poblaciones de aves, y podría estar afectado por la colonización microbiana del intestino. Enterococcus faecalis es un patógeno oportunista común, mientras E. faecium ha sido utilizado como promotor del crecimiento al interactuar competitivamente con bacterias patógenas, incluida E. faecalis. Seguimos el crecimiento en longitud del tarso y peso de 18 nidadas de Ficedula hypoleuca. Los pollos fueron pesados y medidos a los días 4, 8, 10 y 13 de vida. En el día 13, la longitud del ala fue también medida y se tomaron muestras cloacales de dos pollos de cada nidada para la detección de enterococos. En total, los métodos utilizados permitieron detectar 6 especies de bacterias de una comunidad posiblemente mucho más numerosa. La mayoría de los pollos portaban E. faecalis, mientras E. faecium era menos prevalente. Existió una asociación negativa entre la presencia de E. faecalis y la del resto de las especies. La presencia de E. faecalis no mostró una asociación detectable con el peso o tamaño de los pollos a ninguna edad, mientras la presencia de las demás especies mostró asociaciones significativamente positivas con el peso y tamaño en el día 13, pero no antes. La presencia de E. faecium por si misma estuvo positivamente asociada con el peso y tamaño de los pollos poco antes de volar. E. faecium puede actuar como promotor del crecimiento en condiciones naturales a través de interacciones competitivas con bacterias facultativamente patogénicas. La presencia de algunos microbios es de una importancia crítica para el crecimiento y desarrollo de las aves.

${ }^{3}$ E-mail: jmoreno@mncn.csic.es 
THE PURPOSE OF this study was to explore the potential effects of cloacal bacteria on nestling growth in altricial birds. Bacteria are wellknown causes of disease and mortality in poultry and caged birds (Coles 1997). Pathogenic bacteria have also been isolated from birds in the wild (Brittingham et al. 1988, Lombardo et al. 1996, Nuttall 1997, Mills et al. 1999, Lombardo and Thorpe 2000, Westneat and Rambo 2000). However, the potential effect of bacteria on fitness-components of their avian hosts in natural populations has been neglected until recently (but see Pinowski et al. 1995, Lombardo et al. 1996, Singleton and Harper 1998, Burtt and Ichida 1999, Mills et al. 1999, Potti et al. 2002). This lack of attention by ecologists is surprising given the potential importance of pathogens as selective factors in evolution (Hamilton and Zuk 1982, Hamilton 1990, Goater and Holmes 1997). Emphasis on macroparasites and haematozoa instead of on bacteria in the ecological literature (e.g. Hudson et al. 2002) is based on tradition and practical reasons rather than on theoretical expectations.

Nestling growth has frequently been treated without consideration of microbial effects (e.g. O'Connor 1984). Inoculation of altricial nestlings with bacteria is unavoidable, either through the food the parents feed them (Kyle and Kyle 1993) or directly from their parents, from their nest mates, or from the nest itself (Mills et al. 1999). Although effects of cloacal bacteria on birds are known mainly for poultry, some evidence of negative effects of cloacal bacteria on nestling growth in the wild has been found (Lombardo et al. 1996, Mills et al. 1999, Potti et al. 2002). It is known from domestic animals that some bacteria can be beneficial (Fuller 1989). Intestinal bacteria in the gut may entail positive (e.g. probiotics such as lactobacilli) and detrimental consequences, depending on an equilibrium mediated by-among other factors-competitive exclusion of enteric pathogens (Batt et al. 1996, Caldwell et al. 2000). Beneficial effects of some bacteria have also been shown in the rehabilitation of nestling swifts through adult saliva containing various microbes (Kyle and Kyle 1993).

Enterococci are part of the normal bacterial enteric microbiota of captive and wild birds (e.g. Landman et al. 1999, Silvanose et al. 1999, González et al. 2000). One species, Enterococcus faecalis, is a common opportunistic pathogen triggered by immunosuppression and other debilitating factors (Coles 1997). The interaction between different enterococci in chickens (Gallus gallus) is age-dependent (Kaukas et al. 1987) and can be affected by administration of antibiotics (Kaukas et al. 1987, 1988). Some species of Enterococcus may adversely affect $E$. faecalis and other pathogenic bacteria, thus limiting their pathogenic effect in growing birds (CarinaAudisio et al. 2000). Enterococcus faecium has even been used as a growth promoter and typical component of probiotics in birds and other animals (Guillot 1998). Partly it may be due to its production of the so-called enterocins, a family of bacteriocins, which are antimicrobial peptides produced by some bacterial strains. These enterocins could be active against known potential pathogens as for example Salmonella, Listeria, clostridia, bacilli, or staphylococci among others (Laukova et al. 1993, Aymerich et al. 1996, Morovsky et al. 1998). However, the effect of some bacteria as growth promoters in wild birds remains unexplored despite its potential importance based on studies of poultry.

Here, we have addressed the potential growth-promoting effects of several enterococci other than E. faecalis in Pied Flycatcher (Ficedula hypoleuca) nestlings, while controlling for the presence of faecalis. We also tried to discern interactions between different enterococci on the final size and mass of nestlings before fledging. Final mass and size of nestlings at this stage have been found to be crucial determinants of their survival prospects (Lindström 1999). Thus, associations of the presence of certain microbes with these variables could indicate the potential of intestinal bacteria as selective factors in an ecological context. Although focussing on a certain type of bacteria, our aim was to detect potential detrimental or beneficial effects of bacteria in general on nestling growth in altricial birds.

\section{MetHodS}

This study was conducted in 2001 in a deciduous forest of Pyrennean oak (Quercus pyrenaica) at an elevation of 1,200 $\mathrm{m}$ in the vicinity of La Granja, Segovia province, central Spain $\left(40^{\circ} 48^{\prime} \mathrm{N}, 4^{\circ} 01^{\prime} \mathrm{W}\right)$. A study of a population of Pied Flycatchers breeding in nestboxes in that area has been conducted since 1991. Nestboxes $(125 \times 117 \mathrm{~mm}$ bottom area) are cleaned every year after the breeding season. Nestboxes were checked every year for occupation by Pied Flycatchers, and the dates of clutch initiation, clutch sizes, and number of fledged young were determined. 
The Pied Flycatcher is a small (12-13 g) hole-nesting passerine of European woodlands. It is a summer visitor, which adapts readily to breeding in artificial nestboxes. Egg laying in the population under study typically begins in late May, and clutch sizes range from 2 to 8 eggs with a mode of 6 eggs (mean 5.73). The female incubates alone and receives part of her food from her mate. Young are brooded by the female only up to the age of seven days (Sanz and Moreno 1995). Both sexes feed the young (Moreno et al. 1995). Young fledge within 14-16 days of hatching. That occurs in the second half of June in our study area.

A sample of 18 broods of four to six chicks was used for the study of bacteria and growth. On days 4,8 , and 10 (hatching day = day 0 ), tarsus length of chicks was measured with a digital caliper as distance between notch on the back of the intertarsal joint and the lower edge of the last complete scale before toes diverge to the nearest $0.01 \mathrm{~mm}$, and mass was obtained with a portable electronic balance $( \pm 0.1 \mathrm{~g})$. Individual chicks were marked on day 4 by cutting head down and painting claws with TippEx fluid (BIC Deutschland GMBH \& Co., Liederbach, Germany). They were banded on day 8 with numbered aluminum bands (DGCONA). On day 13, all surviving chicks were again measured and weighed in the same manner. Wing length was measured at this age with a stopped ruler to the nearest millimeter.

On day 13, the cloacae of two randomly selected chicks of each brood were sampled with one sterile swab per chick with transport medium AMIES without charcoal (Venturi Transystems, Copan Italia, Brescia, Italy), which is standard for aerobic or facultatively anaerobic bacteria. After reception in the laboratory during the same day, samples were plated by duplicate onto 5\% blood sheep agar (BioMérieux, Madrid, Spain) and incubated aerobically and anaerobically at $37^{\circ} \mathrm{C}$ for $48 \mathrm{~h}$. We also inoculated them into peptone broth, incubated them at $37^{\circ} \mathrm{C}$ for $16 \mathrm{~h}$ (Peptone water, Difco, Detroit, Michigan, USA) and then a small aliquot was transferred into selective enrichment broths or plates as appropriate for enterococci (Enterococcosel, Difco, Detroit, Michigan, USA). Identification was done following routine bacteriological tests plus ad-hoc multisubstrate identification systems (API System, BioMérieux, Madrid, Spain). In total, 32 of 36 swabs (18 broods $\times 2$ ) were used due to contamination of some samples, so for four broods only data on one chick were available.

Presence or absence of E. faecalis and of E. faecium plus the other enterococci were used to check for negative or positive associations with growth, respectively. Scores of presence or absence of different species of enterococci ( 1 or 0 ) were used as categorical factors in GLM-analyses on morphological variables and mass. Given the potential effects of brood size and hatching date on nestling growth, they were introduced as covariables in analyses. Because there were no differences among nests in scores for E. faecalis $(F=0.77, \mathrm{df}=1$ and $14, P=0.68)$ or all non-faecalis species pooled $(F=1.38, \mathrm{df}=1$ and $14, P=0.28)$, we have considered chicks as independent points with respect to bacteria.

\section{RESUlts}

Enterococcus faecalis was detected in 18 of 32 chicks $(56 \%)$. The other five species found were less common. Enterococcus faecium was found in 10 chicks, E. durans in 4 chicks, E. gallinarum in 2, and E. hirae and E. casseliflavus in only 1 each. One chick had three species of enterococci, five had two species, and two had none. The rest had one species. When species other than E. faecalis were present, there were 13 cases in which E. faecalis was absent and 6 in which it was present. On the other hand, when other species were absent, there were 2 cases in which E. faecalis was absent and 11 cases in which it was present. Thus, there was a strongly negative association between the scores for E. faecalis and for the rest of the species pooled $\left(\chi^{2}=6.72, \mathrm{df}=1, P<0.01\right)$.

Presence or absence of $E$. faecalis was not correlated with nestling size or mass at any age in a GLM analysis correcting for possible effects of brood size and hatching date $(P>0.20$ in all cases). Presence of enterococci other than faecalis was positively associated with mass and tarsus length of chicks on day 13, which is near the end of the nestling period, but not at earlier ages (Table 1, Fig. 1). Also, wing length on day 13 was positively associated with presence of enterococci other than faecalis (presence: $46.7 \pm$ $2.0 \mathrm{~mm}, n=14$; absence: $44.4 \pm 3.8, n=15$; Table $1)$. The absence or presence of these species explained $10 \%$ of variation in wing length, $12 \%$ of variation in tarsus length, and $22 \%$ of variation in mass on day 13 . The same result was obtained when considering only the presence or absence of E. faecium (Table 1). Enterococcus faecium on its own explained $15 \%$ of variation in tarsus length and $14 \%$ of variation in mass on day 13 . In the presence of enterococci other than faecalis, especially faecium, chicks apparently grew faster during their last days in the nest and attained a greater size and mass before fledging.

\section{DisCUSSION}

The main results of this study are (1) presence of E. faecalis, an opportunistic pathogen, 

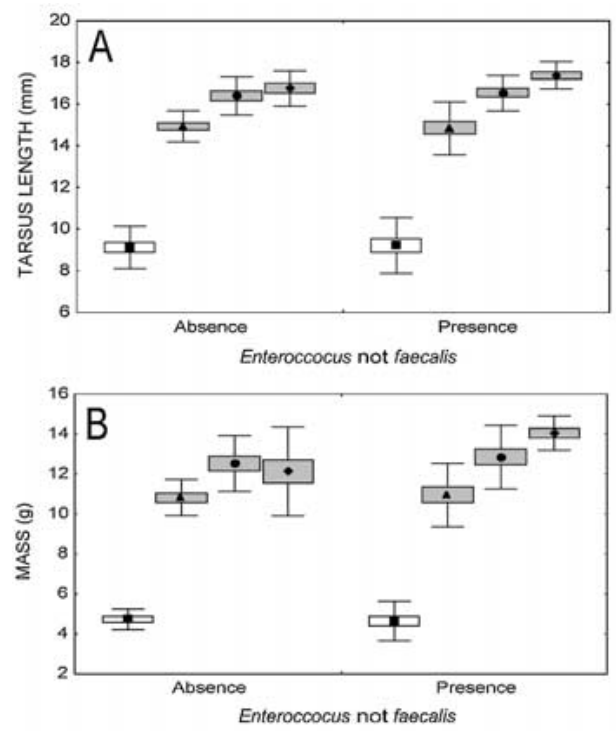

Fig. 1. Mean tarsus length (A) and mass (B) with SE (boxes) and SD (lines) as a function of nestling age for chicks having scored negative or positive for enterococci other than Enterococcus faecalis. Squares represent 4 days, triangles 8 days, circles 10 days, and diamonds 13 days of nestling age.

showed no significant association with nestling growth, and (2) presence of other species of enterococci was positively correlated with growth during the last days in the nest. With respect to the first result, it has been shown previously that colonization of the cloacae of nestling Tree Swallows (Tachycineta bicolor) begins soon after hatching and is progressive (Mills et al. 1999). Given that we sampled bacteria only shortly before fledging and not earlier, it is to be expected that associations of final scores with size and mass should become gradually weaker with time elapsed between measurements of nestlings and sampling of their cloacae. We do not know if bacteria were present also earlier and in which chicks. It is therefore possible that enterococci affected growth also earlier, but that our final scores did not accurately reflect the differential build-up of bacteria populations in chicks. In any case, we can at least conclude that enterococci can be important in the last days before fledging.

Some studies in the wild have detected effects of gastrointestinal bacteria on chick growth. Regulation of intestinal microbiota depends on complex interactions between many
TABLE 1. Results of ANOVA (GLM-STATISTICA) on chick measurements at different ages with presence or absence of Enterococci other than $E$. faecalis as categorical factor and brood size and hatching date as covariates. For the age of 13 days, the analysis using presence or absence of $E$. faecium is also presented.

\begin{tabular}{|c|c|c|c|c|c|c|}
\hline & \multicolumn{2}{|c|}{ E. not faecalis } & \multicolumn{2}{|c|}{ Brood size } & \multicolumn{2}{|c|}{ Hatching date } \\
\hline & $F$ & $P$ & $F$ & $P$ & $F$ & $P$ \\
\hline \multicolumn{7}{|c|}{4 days } \\
\hline Tarsus length & 0.03 & 0.87 & 0.05 & 0.83 & 0.14 & 0.71 \\
\hline Mass & 0.33 & 0.57 & 2.15 & 0.15 & 0.32 & 0.58 \\
\hline \multicolumn{7}{|c|}{8 days } \\
\hline Tarsus length & 0.02 & 0.90 & 0.10 & 0.75 & 1.31 & 0.26 \\
\hline Mass & 0.08 & 0.78 & 0.15 & 0.70 & 1.76 & 0.20 \\
\hline \multicolumn{7}{|c|}{10 days } \\
\hline Tarsus length & 0.85 & 0.36 & 3.79 & 0.06 & 0.75 & 0.39 \\
\hline Mass & 0.55 & 0.46 & 0.61 & 0.44 & 0.09 & 0.77 \\
\hline \multicolumn{7}{|c|}{13 days } \\
\hline Tarsus length & 5.37 & $0.03^{*}$ & 0.81 & 0.38 & 0.01 & 0.92 \\
\hline Mass & 14.60 & $0.001^{*}$ & 7.86 & $0.01^{*}$ & 0.40 & 0.53 \\
\hline Wing length & 5.24 & $0.03^{*}$ & 1.95 & 0.17 & 0.39 & 0.54 \\
\hline \multicolumn{7}{|c|}{13 days } \\
\hline \multicolumn{7}{|l|}{ E. faecium } \\
\hline Tarsus length & 6.15 & $0.02^{*}$ & 0.59 & 0.45 & 0.01 & 0.98 \\
\hline Mass & 7.37 & $0.01^{*}$ & 4.93 & $0.04^{*}$ & 0.46 & 0.50 \\
\hline Wing length & 4.00 & 0.06 & 1.41 & 0.24 & 0.48 & 0.49 \\
\hline
\end{tabular}

factors determined by the host environment, for example secretion of gastric acid, intestinal motility, biliary and pancreatic secretions, local immunity, structure of the inner gut and mucus layers, as well as diet. Interactions among bacteria are important for hosts, which can involve habitat alteration (e.g. role of $\mathrm{pH}$, short-chain fatty acids, oxidation-reduction potential), substrate depletion, and production of bacteriocins inhibiting bacterial growth by some strains (Fons et al. 2000). Beneficial effects of normal enteric microbiota include competitive exclusion of potentially pathogenic organisms (e.g. by resource preemption; Price et al. 1986) and production of nutrients and vitamins (Batt et al. 1996). Detrimental effects of bacteria include competition for calories and features such as adhesion and colonization of intestinal mucosae, in some circumstances causing or contributing to inflammatory disease that may have pathophysiological, sometimes cascading consequences (Batt et al. 1996).

Mills et al. (1999) found a positive correlation of wing asymmetry with plate scores for gramnegative enteric lactose fermentors in Tree 
Swallow nestlings. They suggested an effect of those cloacal bacteria on survival skills for these aerial insectivores, which are highly dependent on flight performance. Lombardo et al. (1996) in the same species found negative correlations of tarsus length and mass with the presence of Salmonella, Shigell, and other enteric bacteria. Potti et al. (2002) found a significant positive effect of antibiotic treatment on the growth of Magellanic Penguin (Spheniscus magellanicus) chicks, which they attributed to the removal of pathogenic bacteria. Although the pathogenic effects of bacteria are well known, the positive effects of symbiotic bacteria have received less attention. Several studies have shown that gastrointestinal bacteria can have important physiological benefits for their hosts through competitive exclusion of potentially pathogenic bacteria, enhanced host nutrition, and enhanced development of host immunocompetence (Hutcheson et al. 1991). Lombardo et al. (1996) found a positive correlation with wing length of colony counts of lactobacilli and other bacteria in nestling Tree Swallows

The pathogenic, opportunistic E. faecalis was the most prevalent species, but its presence was negatively associated with the presence of the rest of the species. That could be explained by competitive interactions between different enterococci (Price et al. 1986). Enterococcus faecium produces enterocins that have proven adverse effects on pathogenic bacteria like Listeria or Salmonella and that could also harm E. faecalis (Laukova et al. 1993, Nettles and Barefoot 1993, Aymerich et al. 1996, Giraffa et al. 1997, Morovsky et al. 1998, Carina-Audisio et al. 2000). It has been also used as growth promoter and probiotic in animal breeding (Fuller 1989, Guillot 1998). However, to our knowledge, nothing is known about its effects on growth in the wild. Here, a strongly significant association between presence of E. faecium together with other scarce enterococci and fledging size and mass has been found. That suggests that E. faecium may act as growth promoter also in natural avian populations. That may have stemmed from elimination of detrimental bacterial strains, proliferation of mutualistic strains, or both. Much work is needed before we can reach some safe conclusions on how, why, and when symbionts such as bacteria act as pathogens or mutualists (Thompson 1994, Frank 1997, Blanco et al. 2001, Frank and Jeffrey 2001). There is a highly complex web of interactions (reviewed by Batt et al. 1996) among the large number of aerobic and anaerobic bacteria of the gastrointestinal tract normally enjoying a symbiotic relationship (sensu Thompson 1994) with their host. However, costs and benefits of particular host-symbiont interactions may vary greatly due to a number of ecological and life-history factors, thus causing conditional outcomes (Bronstein 1994, Blanco et al. 2001).

The growth of nestling birds is crucial for their survival in the nest and after fledging (Alatalo et al. 1990, Lindén et al. 1992). Undersized fledglings may succumb shortly after fledging and have a reduced reproductive value (Hochachka and Smith 1991, Moreno et al. 1999). Those fledglings may also have a low reproductive rate as adults (Both et al. 1999). Any stress that reduces growth may be an important determinant of avian fecundity. Thus, colonization by one or other Enterococcus species may not be trivial for altricial nestlings. The colonization of the digestive tract of nestlings by different species of bacteria could be important for offspring fitness in the wild if these results are confirmed in further studies. There is a strong need for research on bacteria-host interactions in avian populations if we are to fully understand the real ecological effect of the world's most common organisms.

\section{ACKNOWLEDGMENTS}

This study was financed by projects BOS20010587 to J. M. and BOS2000-1125 to S.M. (DGICYTMinisterio de Ciencia y Tecnología). C. Corral and I. Nogueras helped us in the field. We were authorized by J. Donés, Director of "Centro Montes de Valsaín" (Organismo Autónomo Parques Nacionales) to work in the study area. Dirección General del Medio Natural (Junta de Castilla y León) authorized the capture and ringing of birds. This article is a contribution from the field station "El Ventorrillo."

\section{Literature Cited}

Alatalo, R. V., L. Gustafsson, and A. Lundberg. 1990. Phenotypic selection on heritable size traits: Environmental variance and genetic response. American Naturalist 135: 464-471.

Aymerich, T., H. Holo, L. S. HÅverstain, H. Hugas, M. Garriga, and I. F. Nes. 1996. Biochemical and genetic characterization of enterocin $\mathrm{A}$ from Enterococcus faecium, a new antilisterial bacteriocin in the pediocin family of bacterio- 
cins. Applied Environmental Microbiology 62: 1676-1682.

Batt, R. M., H. C. Rutgers, and A. A. Sancak. 1996. Enteric bacteria: Friend or foe? Journal of Small Animal Practice 37: 261-267.

Blanco, G., J. L. Tella, J. Potti, and A. Baz. 2001. Feather mites on birds: Costs of parasitism or conditional outcomes? Journal of Avian Biology 32: 271-274.

Both, C., M. E. Visser, and N. Verboven. 1999. Density-dependent recruitment rates in Great Tits: The importance of being heavier. Proceedings of the Royal Society of London, Series B 266: 465-469.

Brittingham, M. C., S. A. Temple, and R. M. Duncan. 1988. A survey of the prevalence of selected bacteria in wild birds. Journal of Wildlife Diseases 24: 299-307.

BRonsteIn, J. L. 1994. Conditional outcomes in mutualistic interactions. Trends in Ecology and Evolution 9: 214-217.

BurtT, E. H., JR., AND J. M. IchidA. 1999. Occurrence of feather-degrading bacilli in the plumage of birds. Auk 116: 364-372.

Caldwell, D. Y., J. L. McReynolds, S. D. YounG, D. J. Caldwell, and B. M. Hargis. 2000. Development of a rapid and inexpensive assay for the nonspecific detection of antimicrobial residues in chicken egg yolks and neonatal yolk sacs. Journal of Agricultural and Food Chemistry 48: 6431-6434.

Carina-audisio M., G. Oliver, and M. C. Apella . 2000. Protective effect of Enterococcus faecium J96, a potential probiotic strain, on chicks infected with Salmonella Pullorum. Journal of Food Protection 2000 63:1333-1337.

Coles, B. H. 1997. Avian Medicine and Surgery. Blackwell Science, Oxford.

Fons, M., A. Gómez, and T. Karjalainen. 2000. Mechanisms of colonisation and colonisation resistance of the digestive tract: Part 2. Bacteria/bacteria interactions. Microbial Ecology in Health and Disease 12: 240-246.

Frank, S. A. 1997. Models of symbiosis. American Naturalist 150: S80-S99.

Frank, S. A., AND J. S. JeFFrey. 2001. The probability of severe disease in zoonotic and commensal infections. Proceedings of the Royal Society of London, Series B 268: 53-60.

Fuller, R. 1989. Probiotics in man and animals. Journal of Applied Bacteriology 66: 365-378.

Giraffa, G., D. Carminatti, and E. Nevani. 1997. Enterococci isolated from dairy products: A review of risks and potential technological use. Journal of Food Protection 60: 732-738.

Goater, C. P., and J. C. Holmes. 1997. Parasite-mediated natural selection. Pages 9-29 in HostParasite Evolution. General Principles and
Avian Models (D. H. Clayton and J. Moore, Eds.). Oxford University Press, Oxford.

González, S., S. Téllez, C. Ballesteros, M. Blanco, M. García-Montijano, A. García, J. Lemus, AND V. BRIONES. 2000. Intestinal and respiratory microbiota in captive Spanish Imperial Eagles (Aquila adalberti) in Spain. 4th meeting European Wildlife Disease Association, Zaragoza, Spain.

Guillot, J. F. 1998. Probiotics in animal nutrition. Cahiers Agricultures 7: 49-54.

Hamilton, W. D. 1990. Mate choice near or far. American Zoologist 30: 341-352.

Hamilton, W. D., AND M. Zuk. 1982. Heritable true fitness and bright birds: A role for parasites? Science 218: 384-387.

HochachKa, W., and J. N. M. Smith. 1991. Determinants and consequences of nestling condition in Song Sparrows. Journal of Animal Ecology 60: 995-1008.

Hudson, P. J., A. Rizzoli, B. T. Grenfell, H. Heesterbeek, And A. P. Dobson. 2002. The Ecology of Wildlife Diseases. Oxford University Press, Oxford.

Hutcheson, D. P., D. C. Savage, D. S. Parker, R. D. Miles, and S. M. Bootwalla. 1991. Direct fed microbials in animal production: A review of literature. National Feed Ingredients Association, West Des Moines, Iowa.

Kaukas, A., M. Hinton, And A. H. Linton. 1987. The effects of ampicillin and tylosin on the faecal enterococci of healthy young chickens. Journal of Applied Bacteriology 62: 441-447.

Kaukas, A., M. Hinton, And A. H. Linton. 1988. The effect of growth-promoting antibiotics on the faecal enterococci of healthy young chickens. Journal of Applied Bacteriology 64: 57-64.

Kyle, P. D., AND G. Z. Kyle. 1993. An evaluation of the role of microbial flora in the salivary transfer technique for hand-rearing Chimney Swifts. Wildlife Rehabilitation 8: 65-71.

Lauková, A., M. Mareková, AND P. JaVorsK. 1993. Detection and antimicrobial spectrum of bacteriocin-like substance produced by Enterococcus faecium CCM4231. Letters in Applied Microbiology 16: 257-230.

Landman, W. J. M., A. Feberwee, D. R. MekKes, K. T. Veldman, and D. J. Mevius. 1999. A study on the vertical transmission of arthropathic and amyloidogenic Enterococcus faecalis. Avian Pathology 28: 559-566.

LindÉN, M., L. GuSTAFSSON, AND T. PÄRT. 1992. Selection on fledging mass in the Collared Flycatcher and the Great Tit. Ecology 73: 336-343.

LiNDSTRÖM, J. 1999. Early development and fitness in birds and mammals. Trends in Ecology and Evolution 14: 343-348.

Lombardo, M. P., P. A. Thorpe, R. Cichewicz, M. 
Henshaw, C. Millard, C. Steen, C., and T. K. ZelLer. 1996. Communities of cloacal bacteria in Tree Swallow families. Condor 98: 167-172.

Lombardo, M. P., And P. A. Thorpe. 2000. Microbes in Tree Swallow semen. Journal of Wildlife Diseases 36: 460-468.

Mills, T. K., M. P. Lombardo, and P. A. Thorpe. 1999. Microbial colonization of the cloacae of nestling Tree Swallows. Auk 116: 947-956.

Moreno, J., R. J. Cowie, J. J. SAnz, And R. S. R. Williams. 1995. Differential response by males and females to brood manipulations in the Pied Flycatcher: Energy expenditure and nestling diet. Journal of Animal Ecology 64: 721-732.

Moreno, J., A. Barbosa, A. De León, and J.A. FARGALlo. 1999. Phenotypic selection on morphology at independence in the Chinstrap Penguin Pygoscelis antarctica. Journal of Evolutionary Biology 12: 507-513.

Morovský M., P. Pristaš P., S. Czikková, and P. JAVORSKÝ P. 1998. A bacteriocin-mediated antagonism by Enterococcus faecium $\mathrm{BC} 25$ against ruminal Streptococcus bovis. Microbiological Research 153: 277-281.

Nettles, C. G., and S. F. Barefoot. 1993. Biochemical and genetic characteristics of bacteriocins of food-associated lactic acid bacteria. Journal of Food Protection 56:338-356.

Nuttall, P. A. 1997. Viruses, bacteria, and fungi of birds. Pages 271-302 in Host-Parasite Evolution. General Principles and Avian Models (D. H. Clayton and J. Moore, Eds.). Oxford University Press, Oxford.

O'Connor, R. J. 1984. The Growth and Development of Birds. Academic Press, New York.
Pinowski, J., B. P. Kavanagh, And P. Pinowska. 1995. Nestling Mortality of Granivorous Birds Due to Microorganisms and Toxic Substances: Synthesis. Polish Scientific Publishers, Warsaw.

Potti, J., J. Moreno, P. Yorio, V. Briones, P. GarcíaBorboroglu, S. Villar, and C. Ballesteros. 2002. Bacteria divert resources from growth for Magellanic Penguin chicks. Ecology Letters 5: 709-714.

Price, P., M. Westoby, B. Rice, P. P. Atsatt, R. S. Fritz, J. N. Thompson, and K. Mobley. 1986. Parasite mediation in ecological interactions. Annual Review of Ecology and Systematics 17: 487-505.

SAnZ, J. J., AND J. Moreno. 1995. Mass loss in brooding female Pied Flycatchers Ficedula hypoleuca: No evidence for reproductive stress. Journal of Avian Biology 26: 313-320.

Silvanose, C. D., T. A. Bailey, J. H. Samour, And J. L. NALDO. 1999. Intestinal protozoa and associated bacteria in captive Houbara Bustards (Chlamydotis undulata) in the United Arab Emirates. Avian Pathology 28: 94-97.

Singleton, D. R., AND R. C. Harper. 1998. Bacteria in old House Wren nests. Journal of Field Ornithology 69: 71-74.

Thompson, J. N. 1994. The Coevolutionary Process. University of Chicago Press, Chicago.

Westneat, D. F., and T. B. Rambo. 2000. Copulation exposes female Red-winged Blackbirds to bacteria in male semen. Journal of Avian Biology 31: 1-7.

Associate Editor: M. Brittingham 